\title{
Assessment of the geo-environmental effects of activities of auto-mechanic workships at Alaoji Aba and Elekahia Port Harcourt, Niger Delta, Nigeria
}

\author{
Nkanu Ernest Muze' ${ }^{1}$ Alexander Iheanyichukwu Opara', Francis Chizoruo lbe ${ }^{2 *}$ and Okereke Chinwendu Njoku' \\ 'Department of Geology, Federal University of Technology, PMB 1526, Owerri, Nigeria; ${ }^{2}$ Department of Chemistry, Imo State University, PMB 2000, \\ Owerri, Nigeria
}

Geo-environmental assessment of activities of auto-mechanics at Alaoji Aba and Elekahia Port Harcourt, both in the Niger Delta region, Southern Nigeria were carried out with the main objective of determining the extent of soil contamination arising from anthropogenic activities within mechanic villages (MVs). Geochemical analysis of soil samples from the study area revealed that the concentrations of the trace metals ranged from $<1 \mathrm{mg} / \mathrm{kg}$ for chromium $(\mathrm{Cr})$ to $1,925 \mathrm{mg} / \mathrm{kg}$ for the lead $(\mathrm{Pb})$. Soil analysis for polycyclic aromatic hydrocarbon (PAH) and total petroleum hydrocarbon (TPH) across the area revealed concentrations ranging from $<0.02$ to $1.80 \mathrm{mg} / \mathrm{Kg}$ and from $<1.00$ to $38,327 \mathrm{mg} / \mathrm{kg}$ respectively. Elevated levels of the heavy metals and TPH were observed at MV in Alaoji Aba when compared to MV in Elekahia Port Harcourt, and the control sites. These could be attributed to contamination due to the presence of these auto-mechanics in the area for over thirty years. The concentration of $\mathrm{Pb}$ and $\mathrm{Cd}$ recorded in some sample points were above USEPA (United State Environmental Protection Agency) and the National Environmental Standards and Regulations Enforcement Agency (NESREA) permissible limits. Results of PAH analysis showed the presence of naphthalene, phenanthrene, pyrene, fluorene, benzo(a)anthracene, acenaphthene, methylnaphthalene. Risk assessment analysis showed significant geo-accumulation values for $\mathrm{Cd}$ and $\mathrm{Pb}$ indicating heavy contamination. The monomial risk factor of the heavy metals in the MVs are in the order $\mathrm{Cd}$ $>\mathrm{Pb}>\mathrm{Cr}$, while potential ecological risk index analysis showed values indicating very high risk, considerable risk and a moderate risk to the area under study as well as the surrounding environment. These results suggest that the soils from the MVs which represent the mechanic workshops at Alaoji Aba and Elekahia Port Harcourt are considered to be of pollution concern due to elevated $\mathrm{Pb}$ and $\mathrm{Cd}$ levels. Hence, there is a serious need to regularly monitor the activities of auto-mechanics in the study area.

Keywords: Ecological Risk Index, Geo-accumulation Index, heavy metal, mechanic village, polycyclic aromatic hydrocarbon (PAH), total petroleum hydrocarbon (TPH)

\section{Introduction}

Indiscriminate disposal of used engine oil in the environment is considered one of the most potent sources of environmental pollution [1]. The regular use of petroleum-based products like gasoline, diesel, fuel, engine oil and lubricating oil particularly in automobile mechanic villages (MVs) most often results in extensive and inevitable spillage of most of these products in the environment [2]. Motor vehicle and miscellaneous assembly wastes generated in the MVs during

Received: January 18, 2020 Accepted: April 24, 2020

Corresponding author: Francis Chizoruo lbe

Department of Chemistry, Imo State University, PMB 2000, Owerri, Nigeria

E-mail: francispavo@yahoo.com

This article is available from: $h t t p s: / / e a h t . o r g /$ maintenance, repairment or dismantling of motor vehicle parts are usually not properly managed during disposal [3]. The artisans in the business of auto-repairs often dump or spill used engine oils, lubricating oils and other solvents containing petroleum hydrocarbons (PHs) on available space (Figure 1) within their workshops [4]. These spent oils and solvents are among the potentially hazardous wastes often generated in auto-repair workshops in most Nigerian cities [3,5]. The used engine oil contains a mixture of chemicals which include PHs, chlorinated biphenyls, and additives as well as decomposition products and heavy metals resulting from wearing of the engine parts $[2,4]$. These categories of wastes in addition to oil filters, scrap metal parts, lead batteries, and abandoned vehicles which are indiscriminately disposed of are resistant to biodegradation [6]. The presence of these environmental pollutants 

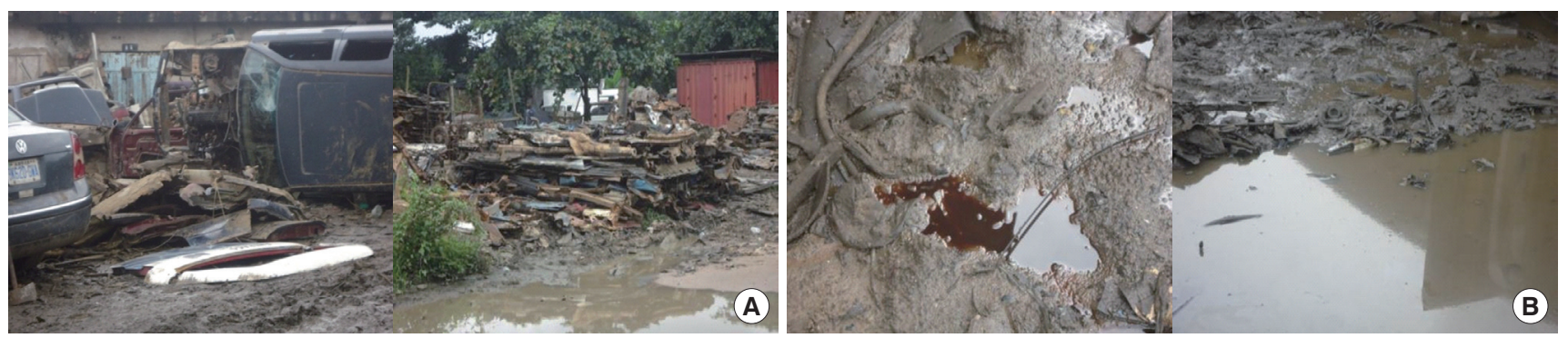

Figure 1. (A) Indiscriminate disposal of motor vehicle scraps at Alaoji Aba mechanic village (MV), (B) Parts of Alaoji Aba mechanic village (MV) showing evidence of poor oil disposal practices.

most often result in the buildup of heavy metals in the soil which may finally find their way into the plant tissues [7]. Also, the migration of the spent oil and percolation of leachates from the materials contained in the oil poses serious threats to the surface and groundwater quality [8-10].

The implication of heavy metals, as well as polycyclic aromatic hydrocarbons (PAHs) and PHs in the environment, is increasingly becoming an issue of global concern especially as the soil makes up an important aspect of the rural and urban environment [11,12]. Oil increases the levels of heavy metals in the soil [13], and as a result of its hydrophobic nature, oil reduces water infiltration into the soil. Several earlier reports revealed that human exposure to elevated concentration of heavy metals particularly children may result in several illnesses such as kidney and liver damage, paralysis, convulsion, depression, and pneumonia [14-16]. Other effects of heavy metals on human health have been reported in several key publications [10,16-18].

Reports on the impact of petroleum products on soils around automobile workshops in Osun State, Nigeria revealed that in addition to the fact that the soil samples were acidic, the concentrations of cadmium $(\mathrm{Cd})$ and lead $(\mathrm{Pb})$ also exceeded the baseline levels [19]. Obini et al. [20] reported high levels of PAHs in soils contaminated with spent motor engine oil in the Abakaliki MV. An assessment of heavy metal contamination in soils within auto-mechanic workshops at Ikare Akoko MV showed remarkably high levels of all the metals such as nickel $(\mathrm{Ni})$, copper $(\mathrm{Cu})$, iron $(\mathrm{Fe})$, chromium $(\mathrm{Cr})$, and $\mathrm{Cd}$ above background concentrations [9]. Similarly, the result of heavy metal contamination in soil and water at automobile junk markets in Obosi and Nnewi, Nigeria revealed elevated manganese $(\mathrm{Mn}), \mathrm{Cr}, \mathrm{Cu}, \mathrm{Fe}, \mathrm{Ni}, \mathrm{Pb}$, and zinc $(\mathrm{Zn})$ above background levels in water and soil [21].

Therefore, there is an urgent need to regularly assess the impact of automobile mechanic workshops on the environment. The need for monitoring and assessment has become necessary as there could be severe contamination of the surrounding air, surface water, groundwater, soil, and river sediments [10,22-24]. Environmental contamination may result from heavy metals, such as $\mathrm{Cd}, \mathrm{Cu}$, and $\mathrm{Pb}$, as well as organic contaminants, like PAHs, polychlorinated biphenyls (PCBs), and poly-brominated diphenyl ethers (PBDEs) $[25,26]$. There is an urgent need to monitor the activities at Alaoji Aba and Elekahia Port Harcourt MVs after more than thirty years of their operation. Besides, there is the need to regularly assess the geo-environmental effect of these activities as there is a paucity of data on the two MVs. This study has the objectives of determining the concentrations of heavy metals such as $\mathrm{Pb}, \mathrm{Cd}$, and $\mathrm{Cr}$, total petroleum hydrocarbon (TPH) and PAHs in soil samples from Alaoji Aba and Elekahia Port Harcourt MVs. The result of the heavy metal analysis will be further subjected to pollution index models for health and environmental risk assessment.

\section{Materials and Methods}

\section{Location and background geology of the study area}

The study area lies between longitudes $7^{\circ} 00^{\prime}$ and $7^{\circ} 30^{\prime} \mathrm{E}$ and latitudes $4^{\circ} 40^{\prime}$ and $5^{\circ} 10^{\prime} \mathrm{N}$. It covers parts of two major cities of the Niger Delta region in Nigeria; the Alaoji MV in Aba, Abia State and the Elekahia MV in Port Harcourt, River State as shown in Figure 2A. The study area is within the sub-equatorial climatic belt characterized by two major seasons, the wet and dry seasons. The wet season generally starts in April and ends in September with peaks in June and July, while the dry season lasts from October to March. However, recent global climate change has affected the duration of these seasons. Rainfall is high in the area with annual averages of between 2,200 $\mathrm{mm}-4,000 \mathrm{~mm}$ with net recharge assumed for the entire area put at 2,270 $\mathrm{mm}$ [27]. The low relative humidity is observed in the dry season mostly from January to March. The rainy period is known for elevated relative humidity levels of about $97 \%$ usually from April to October, and 95\% relative humidity levels are observed within November and December [28]. The daytime temperature is in the range from $18^{\circ} \mathrm{C}$ to 

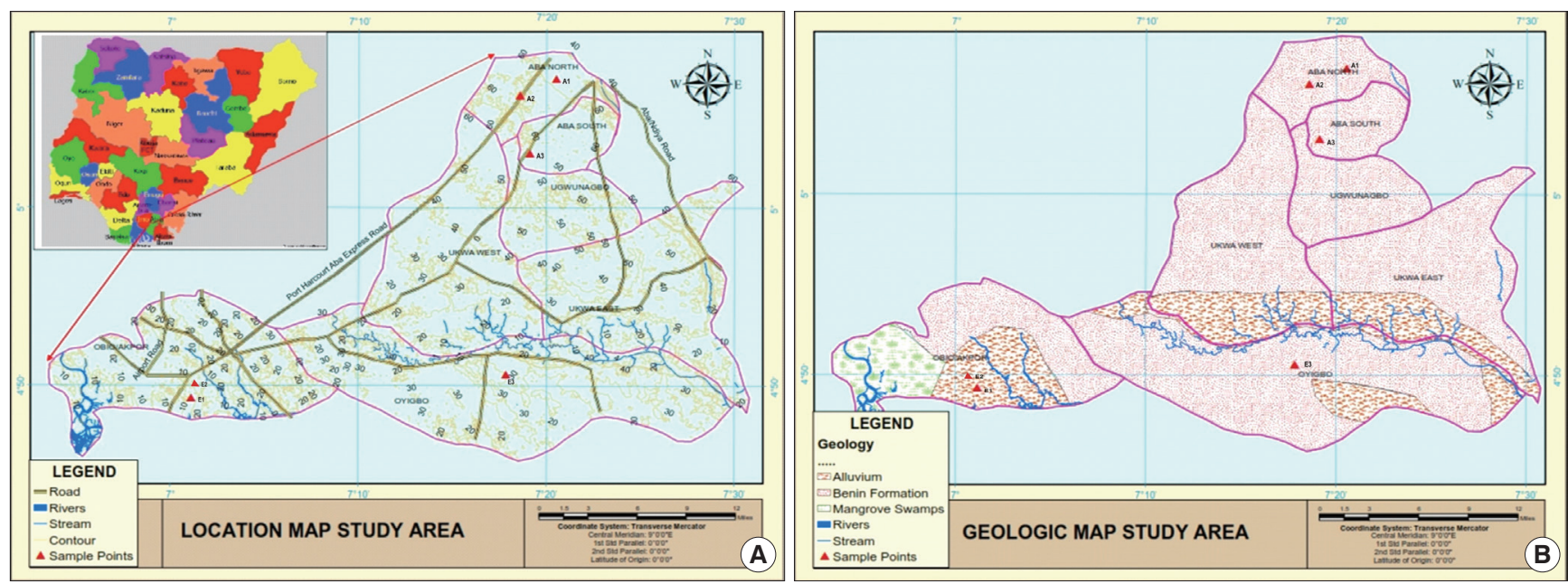

Figure 2. Map and geologic map of the study area.

$34^{\circ} \mathrm{C}$, with daily minimum and maximum average values of $19^{\circ} \mathrm{C}$ and $28^{\circ} \mathrm{C}$, respectively [29]. An estimated evaporation and transpiration rate have been recorded to be $1,450 \mathrm{~mm} / \mathrm{yr}$ and $1,460 \mathrm{~mm} / \mathrm{yr}$, respectively in the area [30].

The study area has low-lying to moderately high plain topography. The study area is characterized by a nearly flat topography. The elevation is generally between $14 \mathrm{~m}$ to $64 \mathrm{~m}$ above sea level. Figure $2 \mathrm{~B}$ is the geological map of the study area. The study area is underlain entirely by the Benin Formation also known as the coastal plain sands [31]. Its age ranges from Miocene to recent. The Benin Formation is an extensive stratigraphic unit in the southern part of the Nigerian sedimentary basin. It extends from the west across the Niger Delta and southward beyond the present coastline. The sediments were deposited in a variety of environments from marine, through the deltaic, estuarine, and coastal swamp to lagoonal and fluvial [32]. The sands are mostly medium to coarse-grained, gravely, locally fine-grained, poorly sorted, subangular to wellrounded, and bears lignite streaks and wood fragments in some places [33,34]. It is over 90 percent of sandstone with minor shale intercalations. Stratigraphically, the Benin Formation is overlain by recent alluvium or recent sediments and underlain by the paralic Agbada Formation.

Alaoji Aba and Elekiahia Port Harcourt MVs have existed for more than thirty years. There are more than two hundred automobile workshops in each of these MV's with about three hundred automobile mechanics and artisans in the business of repairs and sale of auto scrap parts. The activities in these MVs results in dumping or spilling of used engine oils, lubricating oils and other solvents containing PHs within and around the workshops (Figure 1B). The activities of mechanics in these areas could impact negatively on the ecology of these locations (Figure 1B). This problem is compounded by hips of metal scrap and body parts of abandoned vehicles (Figure 1A) within the MVs which could elevate the levels of concentration of heavy metals and other pollutants in the environment.

\section{Sample collection and preparation}

Samples were collected from Alaoji MV in Aba, Abia State and Elekahia MV, Port Harcourt, River State both in the Niger Delta region, Southern Nigeria (Figure 2B). Three soil samples from the top soils at 0-10 $\mathrm{cm}$ depth were collected in triplicate at each sampling point within the selected MVs. The soil samples were collected in June 2018. Soil samples from the same point were homogenized to form a representative sample. In all, a total of six soil samples were collected from the study area. The samples were labeled A1, A2, A3, E1, E2, and E3. A1 and A2 were soil samples collected from Alaoji Aba MV, E1 and E2 were collected from Elekahia Port Harcourt MV, while A3 and E3 stand for Alaoji Aba MV and Elekahia Port Harcourt MV control soil samples. The coordinates of the sample points were referenced with the Garmin, GPS map 76. The samples were taken with the aid of a soil auger at different activity centres within the selected MVs. The control soil samples were taken at distances of between 400 to $500 \mathrm{~m}$ away from the MVs. The soil samples meant for PAH and TPH determination were stored in a dry glass bottle free of grease or oil and labeled appropriately, while the samples for metallic content analysis were collected with polyethylene bags. The soil samples were then transported to the laboratory for analysis in an ice chest.

\section{Determination of heavy metals in soil samples from the} MVs

The soil samples were digested with a mixture of hydrochlo- 
ric and nitric acid (3:1, v/v) at $120^{\circ} \mathrm{C}$ as reported in earlier publications $[18,23,35]$. Concentrations of heavy metals, $\mathrm{Pb}, \mathrm{Cd}$, and $\mathrm{Cr}$ in the soil samples from the MVs were determined with the AAnalyst 400 Perkin Elmer, Atomic absorption spectrometer (AAS). The appropriate calibration curves were prepared to quantify the heavy metal concentrations in the same acid medium with standard metal solutions $[18,23]$.

\section{Measurement of TPH}

The TPH content of the soil samples was extracted according to the methods earlier described by some authors [36-38]. $10 \mathrm{~g}$ of the soil sample was carefully mixed with $150 \mathrm{~mL}$ dichloromethane which was used as the extraction solvent and extracted for 4 hours 30 minutes. This was done in the presence of $2.5 \mathrm{~g}$ of dried sodium sulfate and $300 \mu \mathrm{g} / \mathrm{mL}$ of 1-chloro-octadecane as a surrogate standard. $0.3 \mathrm{~g}$ of silica was introduced into the extraction mixture after the extraction to facilitate the adsorption of polar materials like animal fats and oil from vegetable materials. The extracts were later passed through a Whatman glass fiber filter for filtration. The materials not removed by silica gel such as oil and grease were considered PHs [39]. The separation and determination of TPH contained in the soil samples were carried out with Gas Chromatography equipped with Flame Ionization Detector (GC-FID) (Agilent $6890 \mathrm{~N})$. A concentrated $3 \mu \mathrm{L}$ of the sample was introduced into the GC column with a micro-syringe previously rinsed with dichloromethane (blank) and the sample. The TPH was determined at a specific chromatogram in $\mathrm{mg} / \mathrm{kg}[40,41]$.

\section{Determination of PAH}

The extraction and analysis of soil samples from the MVs for PAH characterization followed the method in Nor et al. [42]. In this method, about $500 \mathrm{mg}$ of the soil samples were dissolved using a mixture of $25 \mathrm{~mL}$-hexane and acetone (7:3, v/v). A microwave extraction arrangement was used with its pressure carefully controlled for 45 minutes. After cooling, the extract was filtered with a Whatman glass fiber filter in a glass bottle, followed by a concentration of the extract to $1.5 \mathrm{~mL}$ using a rotatory evaporator. PAH was determined by the GC quadrupole Mass Spectrometer (GC-MSD) (Agilent 5975 MSD). The sample was separated into its components by chromatographic separation using a capillary column of an internal diameter of $30 \mathrm{~m} \times 0.25 \mathrm{~mm}$ and film thickness of $0.25 \mu \mathrm{m}, \mathrm{HP}-5 \mathrm{MS}$ and a helium carrier gas of high purity (99.5\%), having a flow rate of $1 \mathrm{~mL} / \mathrm{min}$ from a steel cylindrical pipe. The chromatographic separation conditions include an injector temperature of $250^{\circ} \mathrm{C}$ and an initial $70^{\circ} \mathrm{C}$ temperature of the chromatographic column which was held for 1 minute. The temperature in- crease by $30^{\circ} \mathrm{C} / \mathrm{min}$ to $200^{\circ} \mathrm{C}$, by $35^{\circ} \mathrm{C} / \mathrm{min}$ to $250^{\circ} \mathrm{C}$, and by $10^{\circ} \mathrm{C} / \mathrm{min}$ to $300^{\circ} \mathrm{C}$ and this was maintained for 25 minutes. The PAH content of the soil samples was quantified from the resulting chromatogram as earlier reported $[43,44]$.

\section{Quality control}

The integrity of the analytical results was ensured following the use of standard procedures through quality laboratory assurance. The analyses were conducted and the average taken from triplicate runs. Deionized water was double distilled using Eco-Still Mark, BSIC/ECO-4 (Bhanu Scientific Instruments Company, India) before it was used for soil digestion and subsequent metal content determination in soil samples. The reagents and chemicals used for the analysis were of high analytical grade standard and were all sourced from Finlab Nigeria Limited Owerri, Imo State, Nigeria. These chemicals were used without further purification. Crude oil analytical standard was sourced from Nigerian Agip Oil Company, Nigeria, while diesel and petrol standards were obtained from Total Nigeria Ltd. The PAH standard was also sourced from Finlab, Owerri, Nigeria. The glassware and containers were properly washed in detergent, rinsed with deionized water, and dried in an oven (DHG-9023A, B. Brans Scientific and Instrument Company, England). Accuracy and precision were maintained during the determinations with the instruments through the replication of sample analysis alongside the reference standards. The AAS has instrument detection limit (IDL) of 0.1 $\mathrm{mg} / \mathrm{kg}$, with minimum detection limit (MDL) of $0.0008 \mathrm{mg} / \mathrm{kg}$, $0.0008 \mathrm{mg} / \mathrm{kg}$, and $0.015 \mathrm{mg} / \mathrm{kg}$ respectively for $\mathrm{Cd}, \mathrm{Cr}$, and $\mathrm{Pb}$. The IDL of GC-MSD is up to $24 \mathrm{fg}$ with MDL of $0.04 \mu \mathrm{g} / \mathrm{L}$, accuracy of $99.0 \%$ and precision of $8.0 \%$ RSD. GC-FID has MDL of 400 pg-propane/mL and IDL of $1 \mathrm{ng} / \mathrm{L}$, detection module accuracy of less than $\pm 3 \mathrm{~mL} / \mathrm{min}$ NTP with repeatability of less than $\pm 0.35 \%$ of sept point at a temperature coefficient of less than $\pm 0.20 \mathrm{~mL} / \mathrm{min}$ NTP for each rise in temperature $\left({ }^{\circ} \mathrm{C}\right)$ and precision of $0.008 \%$ RSD.

\section{Assessment of pollution indices}

To ascertain the pollution levels of the study locations, the soil samples were assessed for the geo-accumulation index $\left(I_{g e o}\right)$ and the potential ecological risk index.

\section{Geo-accumulation Index ( $\boldsymbol{I}_{\text {geo }}$ )}

$I_{\text {geo }}$ values of the data obtained were used to quantify the extent of the heavy metal pollution of the soil samples. This was calculated according to equation (1) as described by a previous report [45].

$$
I_{g e o}=\log \frac{C_{m s}}{1.5 C_{b}}
$$


where $\mathrm{C}_{\mathrm{ms}}$ is the concentration of the metal in the soil sample and $C_{b}$ is the geochemical background concentration of the metal. The factor of 1.5, accounts for the probable variation in the background concentration of the metals due to lithogenic effect. The world average value in shale was taken as the background concentration in this study, which are $20 \mathrm{mg} / \mathrm{kg}$ for $\mathrm{Pb}$, $90 \mathrm{mg} / \mathrm{kg}$ for $\mathrm{Cr}$ and $0.3 \mathrm{mg} / \mathrm{kg}$ for Cd [46]. The $I_{g e o}$ is usually classified into seven classes ranging from 0 to 6 as follows: $I_{g e o}<0$ is practically uncontaminated; $0<I_{\text {geo }}<1$ uncontaminated to moderately contaminated; $1<I_{\text {geo }}<2$ moderately contaminated; $2<I_{g e o}<3$ moderately to heavily contaminated; $3<I_{g e o}<4$ heavily contaminated; $4<I_{g e o}<5$ heavily to very heavily contaminated sample; $I_{g e o} \geq 5$ is an indication of very heavily contaminated sample [44,47].

\section{Potential ecological risk}

Assessment of potential ecological risk is intended to determine the degree of heavy metal pollution in soils using the toxicity of heavy metals and their response factor in the environment as introduced by Hakanson [48]. The potential ecological risk due to the presence of toxic metals could be calculated using equations (2) to (4).

$$
\begin{aligned}
& P_{i}=\frac{C_{m s}}{C_{b}} \\
& E_{r}^{i}=T_{r}^{i} x P_{i} \\
& R I=\sum_{i=1} E_{r}^{i}
\end{aligned}
$$

where $\mathrm{P}_{\mathrm{i}}$ is the single metal pollution index; $\mathrm{C}_{\mathrm{ms}}$ is the concentration of heavy metal in the soil samples; $C_{b}$ is the reference value for the metal. The target values stated by the Department of Petroleum Resources was chosen for $\mathrm{C}_{\mathrm{b}}$, which is $85 \mathrm{mg} / \mathrm{kg}$ for $\mathrm{Pb}, 100 \mathrm{mg} / \mathrm{kg}$ for $\mathrm{Cr}$ and $0.8 \mathrm{mg} / \mathrm{kg}$ for Cd [44]. $E_{i}^{r}$ represents the monomial potential ecological risk factor while $T_{i}^{r}$ is the metal toxic response factor and the values for each element are in $\mathrm{Cr}=2, \mathrm{~Pb}=5$, and $\mathrm{Cd}=30$ according to Hakanson [48]. RI represents the potential ecological risk index due to the total contamination of the heavy metal studied. The monomial potential ecological risk $\left(E_{i}^{r}\right)$ is classified into five categories: $E_{i}^{r}<40$ is at low risk, $40 \leq E_{i}^{r}<80$ is at moderate risk, $80 \leq E_{i}^{r}<160$ is at considerable risk, $160 \leq E_{i}^{r}<320$ is at high risk and $320 \leq E_{i}^{r}$ is at very high risk. Also, potential ecological risk index (RI) is classified into four categories as follows: $\mathrm{RI}<$ 110 is at low risk, $110 \leq \mathrm{RI}<200$ is at moderate risk, $200 \leq \mathrm{RI}<400$ is at considerable risk and $400 \leq \mathrm{RI}$ is at very high risk [23,46].

\section{Results and Discussion}

\section{Levels of heavy metals and TPH}

The result of soil geochemical analysis for the heavy metals $(\mathrm{Pb}$, $\mathrm{Cr}$, and $\mathrm{Cd}$ ) and their allowed limits are presented in Table 1.

The results showed that $\mathrm{Pb}$ concentrations within the study sites were between 130 and $1,925 \mathrm{mg} / \mathrm{kg}$. These values were much higher than the concentrations recorded at control sample points A3 and E3 with $40 \mathrm{mg} / \mathrm{kg}$ and $24 \mathrm{mg} / \mathrm{kg}$ respectively. The concentrations recorded for lead were higher than the permissible value of $50 \mathrm{mg} / \mathrm{kg}$ by USEPA, but within NESREA's limit of $164 \mathrm{mg} / \mathrm{kg}$ for samples A2 and E2, while samples Al and El were far above NESREA's limit of $164 \mathrm{mg} / \mathrm{kg}$.

The $\mathrm{Cr}$ concentration levels obtained in the study area were lower than $2 \mathrm{mg} / \mathrm{kg}$ which are higher than the values obtained for the control sample points. The recorded values were generally much lower than the allowed values of 50 and $100 \mathrm{mg} / \mathrm{kg}$ by USEPA and NESREA respectively. Cd concentration levels was less than $1 \mathrm{mg} / \mathrm{kg}$ to $8.5 \mathrm{mg} / \mathrm{kg}$ for the study area. The observed values were higher than the control values of less than $1 \mathrm{mg} / \mathrm{kg}$ and also higher than the allowed value of $1 \mathrm{mg} / \mathrm{kg}$ by USEPA. The recorded values were also found to be higher than NESREA's limit of $3 \mathrm{mg} / \mathrm{kg}$ except for sample A2 which was less than $2 \mathrm{mg} / \mathrm{kg}$.

The percentage concentration of $\mathrm{Pb}, \mathrm{Cd}$, and $\mathrm{Cr}$ in the soil samples A1, A2, E1, and E2 are presented in Figures 3A-D. Similarly, the percentage concentrations of $\mathrm{Pb}, \mathrm{Cd}$, and $\mathrm{Cr}$ in the control samples A3 and E3 are shown in Figure 3E and 3F. Samples within the study area revealed elevated levels of lead followed by minimal $\mathrm{Cd}$ and very low $\mathrm{Cr}$ concentrations. The control sites showed lead presence but with very insignificant concentrations when compared with the study areas.

TPH concentration levels recorded in the soil samples exam-

Table 1. Result of soil geochemical analysis for heavy metals and total petroleum hydrocarbon (TPH)

\begin{tabular}{lrrrrrrrr}
\hline Parameters & \multicolumn{1}{c}{$\mathrm{A} 1$} & \multicolumn{1}{c}{$\mathrm{A} 2$} & $\mathrm{~A} 3$ & \multicolumn{1}{c}{ E1 } & \multicolumn{1}{c}{ E2 } & E3 & NESREA & USEPA \\
\hline $\mathrm{Pb}(\mathrm{mg} / \mathrm{kg})$ & 1925.00 & 144.00 & 40.00 & 350.00 & 130.00 & 24.00 & 164.00 & 50.00 \\
$\mathrm{Cr}(\mathrm{mg} / \mathrm{kg})$ & $<1.00$ & $<1.00$ & $<1.00$ & 1.93 & 1.50 & $<1.00$ & 100.00 & 50.00 \\
$\mathrm{Cd}(\mathrm{mg} / \mathrm{kg})$ & 8.500 & $<2.00$ & $<1.00$ & 3.70 & 5.50 & $<1.00$ & 3.00 & 1.00 \\
$\mathrm{TPH}(\mathrm{mg} / \mathrm{kg})$ & $1,150.00$ & $38,327.00$ & $<1.00$ & 970.00 & $1,075.00$ & 1.70 & Nil & 30.00 \\
\hline
\end{tabular}

*Pb: lead; Cr: chromium; Cd: Cadmium; A1 and A2: Alaoji Aba mechanic villages (MV); E1 and E2: Elekahia Port Harcourt MV study site; A3 and E3: control sample at Alaoji Aba and Elekahia Port Harcourt; NESREA: permissible limit determined by National Environmental Standards and Regulations Enforcement Agency; USEPA: permissible limit determined by United State Environmental Protection Agency. 

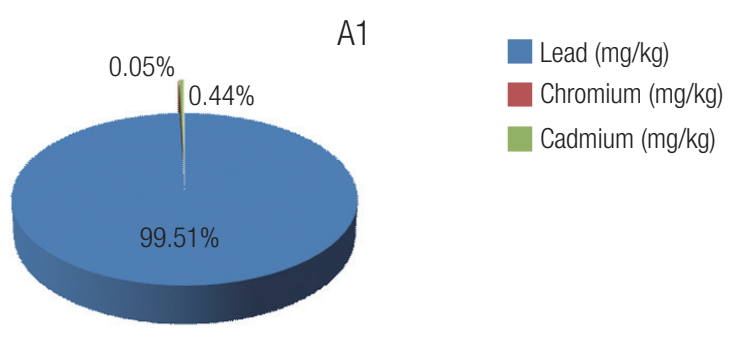

A

E1

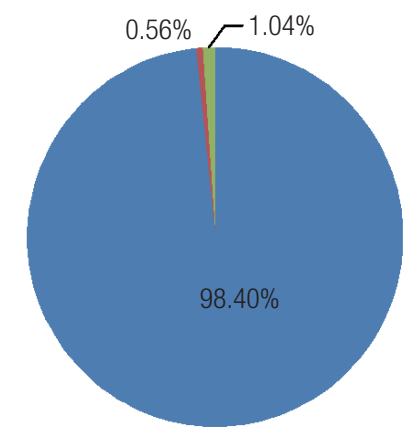

Lead ( $\mathrm{mg} / \mathrm{kg})$

Chromium (mg/kg)

Cadmium (mg/kg)

A3

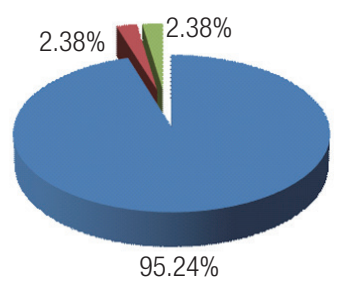

Lead $(\mathrm{mg} / \mathrm{kg})$

Chromium $(\mathrm{mg} / \mathrm{kg})$

Cadmium $(\mathrm{mg} / \mathrm{kg})$

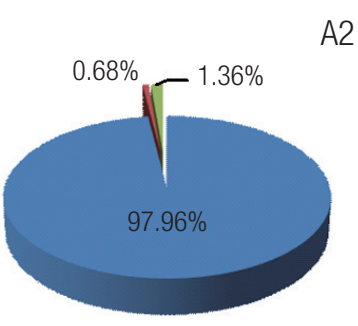

Lead $(\mathrm{mg} / \mathrm{kg})$

Chromium (mg/kg)

Cadmium (mg/kg)
B

E2

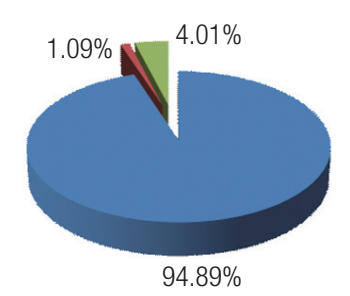

Lead (mg/kg)

Chromium (mg/kg)

Cadmium (mg/kg)

D

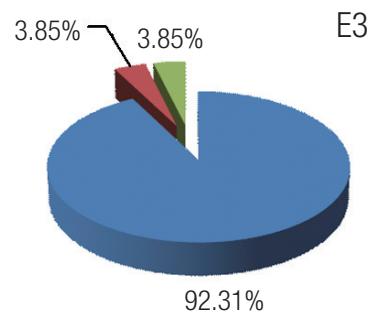

Lead (mg/kg)

Chromium (mg/kg)

Cadmium (mg/kg)

Figure 3. Pie charts of percentage concentrations of heavy metals from the studied MVs. *A1 and A2: Alaoji Aba mechanic villages (MV); E1 and E2: Elekahia Port Harcourt MV study site; A3 and E3: control sample at Alaoji Aba and Elekahia Port Harcourt.

ined within the vicinity of the MVs were between $970 \mathrm{mg} / \mathrm{kg}$ and $38,327 \mathrm{mg} / \mathrm{kg}$ as indicated in Table 1 . The TPH concentrations were above $0.08 \mathrm{mg} / \mathrm{kg}$ and $1.7 \mathrm{mg} / \mathrm{kg}$ for the control sample points and higher than background values by the department of petroleum resources and New South Wales recommended maximum permissible limit of $1,000 \mathrm{mg} / \mathrm{kg}$ except for El which was $970 \mathrm{mg} / \mathrm{kg}[49,50]$. The concentrations of TPH across the study area and control sample points as presented in Table 1 revealed very high concentrations of TPH in the soil samples A1, A2, E1, and E2 within the study area. The TPH concentrations of the control samples A3 and E3 were extremely low. A comparison of the results of TPH levels for A1, A2, E1, and E2 with A3 and E3 suggested that the observed levels of TPH at Alaoji Aba and Elekahia Port Harcourt MVs are mainly due to the activities of the automobile mechanics in the respective MVs. Elevated levels of TPH and heavy metals within and around automobile mechanics have been reported in important publications $[9,19]$.

\section{Concentration of PAHs}

Table 2 is the result of the concentrations of the total PAH within the study area and the control samples. Table 2 revealed mean PAH levels of 0.09, 1.13, 0.02, 0.13, 0.46, and $0.03 \mathrm{mg} / \mathrm{kg}$ respectively for $\mathrm{A} 1, \mathrm{~A} 2, \mathrm{~A} 3, \mathrm{E} 1, \mathrm{E} 2$, and $\mathrm{E} 3$, suggesting elevated levels of PAH in the soil samples from the MVs (A1, A2, E1, and E2) compared to the PAH values recorded at the control sample points (A3 and E3). As shown in Table 2, a total of seventeen PAHs were recorded in the analyzed soil samples. Higher concentrations of PAHs were observed in sample A2 compared to other samples. Elevated levels of pyrene $(3.09 \mathrm{mg} /$ $\mathrm{kg})$, fluorene $(1.78 \mathrm{mg} / \mathrm{kg})$, and fluoranthene (1.59) were recorded in sample A2, pyrene $(2.60 \mathrm{mg} / \mathrm{kg})$ and $1.80 \mathrm{mg} / \mathrm{kg}$ of phenanthrene were the highest concentration of PAH recorded in sample E2 as A1, A3, E1, and E3 recorded values less than unity. The observed elevated levels of PAH's at A2 may not be unconnected with the prolonged activities at the Alaoji Aba MV, which has existed for over thirty years.

The recorded PAHs values within the study area are higher 
Nkanu Ernest Muze, et al. I Assessment of the geo-environmental effects of auto-mechanic workshops

Table 2. Results of soil analysis for polycyclic aromatic hydrocarbon (PAH) (mg/kg)

\begin{tabular}{|c|c|c|c|c|c|c|c|c|c|c|}
\hline Parameters & Abbr. & A1 & A2 & A3 & E1 & E2 & E3 & Mean & SD & Var \\
\hline Naphthalene & Nap & 0.25 & 0.96 & 0.01 & 0.04 & 0.15 & 0.01 & 0.24 & \pm 0.37 & 0.13 \\
\hline Methylnaphthalene & Mepl & 0.14 & 1.23 & 0.04 & 0.06 & 1.57 & 0.08 & 0.52 & \pm 0.69 & 0.48 \\
\hline Acenapthylene & Acpt & 0.02 & 0.37 & 0.02 & 0.12 & 0.05 & 0.04 & 0.10 & \pm 0.14 & 0.02 \\
\hline Acenaphthene & Acph & 0.02 & 1.12 & 0.01 & 0.07 & 0.18 & 0.07 & 0.25 & \pm 0.43 & 0.19 \\
\hline Fluorene & Flu & 0.06 & 1.78 & 0.01 & 0.01 & 1.80 & 0.03 & 0.62 & \pm 0.91 & 0.83 \\
\hline Phenanthrene & Phe & 0.20 & 1.52 & 0.03 & 0.03 & 0.04 & 0.08 & 0.32 & \pm 0.59 & 0.35 \\
\hline Anthracene & An & 0.05 & 0.79 & 0.02 & 0.02 & 0.09 & 0.06 & 0.17 & \pm 0.30 & 0.09 \\
\hline Fluoranthene & $\mathrm{Fla}$ & 0.07 & 1.59 & 0.01 & 0.09 & 0.04 & 0.01 & 0.30 & \pm 0.63 & 0.4 \\
\hline Pyrene & Pyr & 0.12 & 3.09 & 0.02 & 0.02 & 2.60 & 0.04 & 0.98 & \pm 1.45 & 2.12 \\
\hline Benzo (a) anthracene & $\mathrm{Ba}$ & 0.06 & 1.54 & 0.03 & 0.04 & 0.08 & 0.05 & 0.30 & \pm 0.61 & 0.37 \\
\hline Chrysene & Chy & 0.14 & 0.62 & 0.01 & 0.13 & 0.01 & 0.01 & 0.15 & \pm 0.24 & 0.06 \\
\hline Benzo (b) fluoranthene & $\mathrm{Bbf}$ & 0.01 & 0.24 & 0.02 & 0.99 & 0.18 & 0.03 & 0.25 & \pm 0.38 & 0.14 \\
\hline Benzo (k) fluoranthene & Bkf & 0.07 & 0.48 & 0.01 & 0.05 & 0.04 & 0.01 & 0.11 & \pm 0.18 & 0.03 \\
\hline Benzo (g) pyrene & $B(g) p$ & 0.09 & 0.92 & 0.03 & 0.08 & 0.07 & 0.01 & 0.20 & \pm 0.35 & 0.13 \\
\hline Dibenzo $(a, h)$ anthracene & $\mathrm{Da}$ & 0.02 & 1.50 & 0.01 & 0.01 & 0.12 & 0.01 & 0.28 & \pm 0.60 & 0.36 \\
\hline Benzo $(g, h, i)$ perylene & B(ghi)p & 0.11 & 0.99 & 0.09 & 0.12 & 0.61 & 0.03 & 0.33 & \pm 0.39 & 0.15 \\
\hline Indeno (1, 2, 3-d) pyrene & Ind & 0.04 & 0.48 & 0.03 & 0.03 & 0.13 & 0.01 & 0.12 & \pm 0.18 & 0.03 \\
\hline Sum of LMW PAHs & & 0.74 & 7.77 & 0.14 & 0.35 & 3.88 & 0.37 & & & \\
\hline Sum of HMW PAHs & & 0.73 & 11.45 & 0.26 & 1.56 & 3.88 & 0.21 & & & \\
\hline Total PAH & & 1.45 & 19.20 & 0.40 & 1.91 & 7.76 & 0.58 & & & \\
\hline Mean & & 0.09 & 1.13 & 0.02 & 0.13 & 0.46 & 0.03 & & & \\
\hline SD & & \pm 0.07 & \pm 0.69 & \pm 0.02 & \pm 0.23 & \pm 0.77 & \pm 0.03 & & & \\
\hline Var & & 0.00 & 0.48 & 0.00 & 0.05 & 0.59 & 0.00 & & & \\
\hline
\end{tabular}

*SD: standard deviation; Var: variance; Abbr.: abbreviation; LMW: low molecular weight; HMW: high molecular weight; A1 and A2: Alaoji Aba mechanic villages (MV); E1 and E2: Elekahia Port Harcourt MV study site; A3 and E3: control sample at Alaoji Aba and Elekahia Port Harcourt.

than the recommended levels of $1,000 \mu \mathrm{g} / \mathrm{kg}, 1,500 \mu \mathrm{g} / \mathrm{kg}$, and $5 \mathrm{mg} / \mathrm{kg}$ recommended by soil clean-up guidelines from Denmark, the Netherlands and Australia respectively [47-53]. The high PAHs content of the soil samples within the study area is an indication of contamination of the study sites. Samples taken from the control sites that were a distance away from the study sites were lower than the recommended levels of 1,000 $\mu \mathrm{g} / \mathrm{kg}$, and $1,500 \mu \mathrm{g} / \mathrm{kg}$ recommended by soil clean-up guidelines from the Netherlands and Australia respectively [47-53].

The high-level of $\mathrm{Pb}$ observed in the soil from the study area could be from the indiscriminate disposal of waste from leadacid batteries, lead-based solder; metallic alloy, lead-based paints, used oil, waste incineration, scrap and junk part of automobile [54]. These parts may be coated with oil or grease, which may contain lead residues that may in the long run harmfully affect storm water runoff that may further endanger aquatic life and public drinking water supplies. Also, leachates from these wastes via storm water run-off could infiltrate in the groundwater system. Aquifers are known to be vulnerable to various contaminants and sediment loads including microscopic bacteria, viruses, and protozoa [55]. Seepage and infiltrations of pollutants from surface water could also affect the quality of groundwater. $\mathrm{Pb}$ has no known biological benefit to humans as it can damage various systems of the body including the nervous system, reproductive system, and the kidney, and can further cause high blood pressure and anaemia [56]. The minimal $\mathrm{Pb}$ levels in control samples might be of natural origin since there is no known industrial activity at the control site. Cd was also found to be relatively high except for sample point A2 which was less than $2 \mathrm{mg} / \mathrm{kg}$. The high Cd concentrations in the study area may be a result of the disposal of waste containing $\mathrm{Cd}$ such as waste batteries and paints.

Alinnor and Nwachukwu reported that soil samples in parts of Rivers State, Nigeria were contaminated with TPH concentrations of 1,534.7 mg/ $/ \mathrm{kg}, 1,438.0 \mathrm{mg} / \mathrm{kg}$, and 1,651.0 mg/ $/ \mathrm{kg}$ at depths of 0.0 to $0.5 \mathrm{~m}, 0.5$ to $1.0 \mathrm{~m}$ and 1.0 to $2.0 \mathrm{~m}$, respectively [41]. The above values are higher than values obtained in this study, except A2 which is $38,327 \mathrm{mg} / \mathrm{kg}$ [41]. According to Iturbe et al. [45], the soils of Coastal Mexican Refinery were heavily contaminated with hydrocarbons with detectable TPH concentration in the region of $130,000 \mathrm{mg} / \mathrm{kg}$. This value was higher than those recorded in this work. Ogoko reported PAHs and TPH values which ranged from 6.30 to $7.40 \mathrm{mg} / \mathrm{kg}$ and $5,120.50$ to $24,902.23 \mathrm{mg} / \mathrm{kg}$ respectively at NNPC Depot Aba, which was above values reported in the present study [39]. The observed elevated concentrations of TPH and PAH in the study area may be attributed to indiscriminate disposal and handling of used/spent petroleum products [39].

The high PAH is an indication of soil contamination by $\mathrm{PAH}$ within the study area. The source of the PAH may be products 
of incomplete combustion of fossil fuel while other important sources may include automobile and truck emissions. The observed differences in the concentration of the pollutants in the two MVs may be attributed to the number of years the mechanic workshops may have been in operation, the volume of work done at each site, types of automobiles serviced or repaired, types of lubricant commonly used, mode of wastes disposal and type of soil [9].

\section{The diagnostic ratio of the PAHs}

Diagnostic ratios have been used as a method of identification of PAH sources, which is important in distinguishing between natural and anthropogenically generated PAHs in the environment [57]. Though some uncertainties are associated with the use of diagnostic ratios [58], however, the method has been adopted in the determination of PAH point sources by many researchers to locate contamination of the environment by PAH. The result of the diagnostic ratio of the PAHs is presented in Table 3. The observed ratio of phenanthrene to anthracene is suggestive of pyrogenic origin [59]. It was observed that An/Phe+An values were all less than one, which implies that the PAHs are of petrogenic origin. The values of the ratio Fla/Pyr were all less than one except in sample E1, suggesting that the PAHs in sample A1, A2, A3, E2, and E3 are of petrogenic origin while that of $\mathrm{E} 1$ is of pyrogenic origin [57]. Also, the values recorded for Fla/Pyr+Fla in all the sample sites were less than 0.5 except in sample E1, which indicates that the PAHs are due to emissions from petroleum products, while that of sample E1 is due to diesel emissions [57]. This is possibly due to the activities of automobile mechanics in the MVs under investigation. The ratio of $\mathrm{Ba} / \mathrm{Ba}+\mathrm{Chy}$ in the study locations was 0.24 and 0.30 at E1 and $\mathrm{A} 1$ respectively, indicating the presence of these PAHs in the study area due to the combustion of carbonaceous materials. The other samples revealed values which are more than 0.35 , indicating PAHs due to the presence of vehicular emissions as well as combustion. The values recorded for the ratio; Ind/Ind+B(ghi)p as shown in Table 3 is an indication that the PAHs are likely due to the combustion of petroleum products as well as biomass [57].
The values recorded for the ratio of low molecular weight to high molecular weight (LMW/HMW) more than lis suggestive of petrogenic sources, while the ratio less than 1 indicates pyrogenic sources of the PAHs. Finally, the values for Mepl/ Phe as shown in Table 3 no doubt revealed the presence of PAHs due to the combustion of fossil fuel [60], indicating anthropogenic activities in the MVs under investigation.

\section{Indices of pollution}

The detailed result of $I_{\text {geo }}$ analysis of the heavy metals at different locations is presented in Figure 4A. The results indicate that the $I_{\text {geo }}$ of the heavy metals is in the order $\mathrm{Pb}>\mathrm{Cd}>\mathrm{Cr}$. The $I_{\text {geo }}$ data except for $\mathrm{Cr}$ at A1, A2, A3, E2, and E3 suggests that the contamination level is alarming and calls for urgent environmental attention. The $I_{g e o}$ values for $\mathrm{Cd}$ and $\mathrm{Pb}$ are very far above unity except at A3 and E3, which indicates moderately contaminated to very heavily contaminated samples. It was observed that $\mathrm{Cd}$ and $\mathrm{Pb}$ at $\mathrm{Al}$ showed significant $I_{\text {geo }}$ values which imply that Alaoji Aba MV is very heavily contaminated with $\mathrm{Cd}$ and $\mathrm{Pb}$. The contamination levels of $\mathrm{Cd}$ and $\mathrm{Pb}$ are an indication of anthropogenic influence due to the activities of automobile mechanics in the studied MVs [9].

The result of the ecological risk factor and potential ecological risk of the heavy metals are presented in Figures $4 \mathrm{~B}$ and 4C. The monomial risk factor of the heavy metals in the soil samples from the MVs is in the order of $\mathrm{Cd}>\mathrm{Pb}>\mathrm{Cr}$ as shown in Figure 4B. This is an indication that Cd posed moderate to high risk, while $\mathrm{Pb}$ posed a considerable risk. The results suggest that the presence of these heavy metals posed moderate to high risk not only to the region but to the ecosystem. The monomial ecological risks factor of $\mathrm{Cr}$ at all the sample sites including the control were all below 40, showing that the observed concentrations of the metals posed no risk to the environment.

The RI was determined in an attempt to quantify the total potential ecological risk associated with the heavy metals in the soil samples from the MVs as indicated in Figure 4C. A1, $\mathrm{E} 2$, and E1 respectively represent a very high risk, considerable risk and moderate risk to the area under study as well as the

Table 3. Diagnostic Ratio of PAHs in the study area

\begin{tabular}{|c|c|c|c|c|c|c|c|c|c|}
\hline Sample site & $\frac{P h e}{A n}$ & $\frac{A n}{P h e+A n}$ & $\frac{\text { Fla }}{\text { Pyr }}$ & $\frac{\text { Fla }}{P y r+F l a}$ & $\frac{B(a) p}{\text { Chy }}$ & $\frac{B a}{B a+C h y}$ & $\frac{\operatorname{lnd}}{\operatorname{lnd}+B(g h i) p}$ & $\frac{\text { Mepl }}{\text { Phe }}$ & $\frac{H M W}{L M W}$ \\
\hline A1 & 4.00 & 0.20 & 0.58 & 0.29 & 0.64 & 0.30 & 0.27 & 1.43 & 1.01 \\
\hline$A 2$ & 1.92 & 0.34 & 0.51 & 0.34 & 1.48 & 0.71 & 0.33 & 1.24 & 0.68 \\
\hline A3 & 1.50 & 0.40 & 0.50 & 0.33 & 3.00 & 0.75 & 0.25 & 0.75 & 0.54 \\
\hline E1 & 1.50 & 0.04 & 4.50 & 0.82 & 0.62 & 0.24 & 0.20 & 0.75 & 0.22 \\
\hline E2 & 0.44 & 0.69 & 0.02 & 0.02 & 7.00 & 0.89 & 0.93 & 0.03 & 1.00 \\
\hline E3 & 1.33 & 0.43 & 0.25 & 0.20 & 1.00 & 0.83 & 0.25 & 1.00 & 1.76 \\
\hline
\end{tabular}



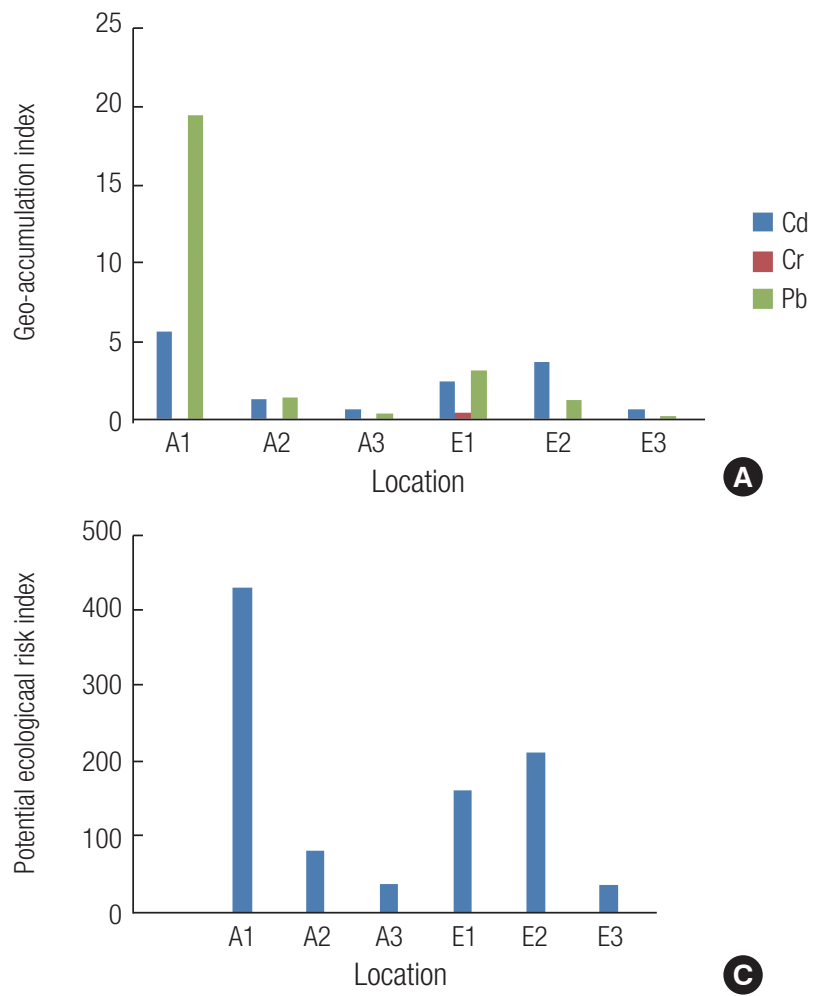

C

surrounding environment. Low risk to the environment was observed in the cases of A2, A3, and E3. The RI describes the impact of heavy metals on the local ecosystem and signifies the ecological risk due to overall pollution.

The high values of $I_{g e o}, E_{i}^{r}$, and RI of the heavy metals in most of the study locations could be attributed to the activities of the automobile mechanics in the MVs. Activities such as indiscriminate disposal of spent engine oil, discarded vehicle spare parts as well as other maintenance activities could increase the overall heavy metal contamination burden of the environment.

\section{Conclusion and recommendations}

The geochemical investigation of the study revealed that anthropogenic factors such as indiscriminate disposal and poor management of waste generated by artisans in the MVs are responsible for the observed level of soil pollution. The concentrations of heavy metals, TPH and PAH determined in the soil samples obtained from the two MVs in this study are evidently above the permissible levels for most of the parameters examined. Diagnostic ratio analysis suggests that the PAHs are majorly due to petroleum products from the automobiles serviced in the MVs. It was observed that Alaoji Aba MV recorded higher concentrations of all the measured parameters, which is associated with the level of anthropogenic activities in this

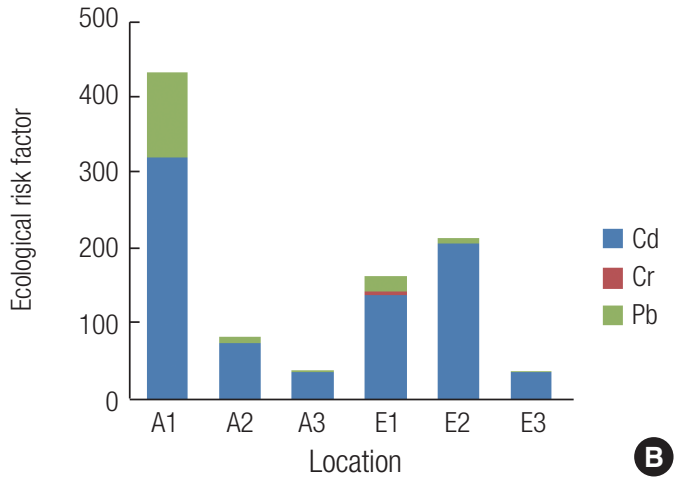

Figure 4. (A) Geo- accumulation index of the heavy metal at different locations (B) Ecological risk factor and (C) potential ecological risk of the heavy metals. "Pb: lead; Cr: chromium; Cd: Cadmium; A1 and A2: Alaoji Aba mechanic villages (MV); E1 and E2: Elekahia Port Harcourt MV study site; A3 and E3: control sample at Alaoji Aba and Elekahia Port Harcourt.

MV. Alaoji Aba MV doubles as a regional automobile spare parts/scrap metals market as well as a major MV coupled with the long duration of activities of the artisans in the area. The geological formation (Benin Formation) of the area could have also influenced the observed levels of the analyzed parameters as well as the prolonged rainy periods which may retard the evaporation of spilled used engine oil.

Risk assessment analysis showed that $\mathrm{Cd}$ and $\mathrm{Pb}$ at $\mathrm{Al}$ have significant $I_{g e o}$ values which imply that Alaoji Aba MV is very heavily contaminated with $\mathrm{Cd}$ and $\mathrm{Pb}$. The overall $\mathrm{RI}$ result revealed that the presence of these heavy metals poses moderate to high risk not only to the region but to the entire ecosystem. The observed level of contamination could be associated with the porosity, high permeability, and transitivity of the Benin Formation. There could be a heavy metal build-up in these MVs, which may be risky over time as it may lead to pollution of groundwater systems and nearby farmlands if no monitoring programme is put in place to check the activities of the auto-mechanics in this area.

The environmental and public health hazards associated with the indiscriminate siting of MVs without prescribed standards by the authorities outweigh the current benefit derived from this practice. There is, therefore, a need to decongest or relocate the MVs to a more geologically appropriate location with formations characterized by very low permeability. 


\section{Conflicts of interest}

The authors declare that there is no conflicting interest regarding the publication of this article.

\section{CRediT author statement}

ENM: Concepualization, Methology, Software, Data Curation, Visualization, Investigation, Writing - Original Draft; AIO: Conceptualization, Methodology, Software, Visualization, Investigation, Supervision, Writing - Reviewing and Editing; FCI: Conceptualization, Methology, Software, Data Curation, Writing - Original Draft, Supervision, Writing - Reviewing and Editing; OCN: Conceptualization, Methodology, Software, Visualization, Investigation.

\section{References}

1. Odjegba VJ, Sadiq AO. Effects of spent engine oil on the growth parameters, chlorophyll and protein levels of Amaranthus hybridus L. The Environmentalist 2002; 22(1):23-28.

2. Kidman RL, Boehlecke R. Evaluating Petroleum Hydrocarbon-Contaminated Soil. WM 2011 Conference, February 27-March 3, 2011, Phoenix, AZ.

3. Ipeaiyeda AR, Dawodu M. Heavy metals contamination of topsoil and dispersion in them vicinities of reclaimed auto-repair workshops in Iwo, Nigeria. Bull Chem Soc. Ethiopia 2008;22(3):339-348.

4. Wang J, Jia CR, Wong CK, Wong PK. Characterization of polycyclic aromatic hydrocarbon created in lubricating oils. Water Air Soil Pollut 2000;120(3-4):381-396.

5. Iwegbue CM. Metal fractionation in soil profiles at automobile mechanic waste dumps around Port Harcourt. Waste Manag Res 2007; 25(6):585-593.

6. Ang EL, Zhao H, Obbard JP. Recent advances in bioremediation of persistent organic pollutants via biomolecular engineering. Enzyme and Microbial Technol, 2005;37(5):487-496.

7. Vwioko DE, Anoliefo GO, Fashemi SD. Metals concentration in plant tissues of Ricinus communis L. (Castor Oil) grown in soil contaminated with spent lubricating oil. J Appl Sci Environ Manag 2006;10(3): 127-134.

8. Olugboji OA, Ogunwole OA. Use of spent engine oil. AU JT 2008;12(1): 67-71.

9. Ololade IA. An assessment of heavy-metal contamination in soils within auto-mechanic workshops using enrichment and contamination factors with geoaccumulation indexes. J Environ Protection 2014; 5:970-982.

10. Ibe FC, Opara AI, Ibe BO, Amaobi CE. Application of assessment models for pollution and health risk from effluent discharge into a tropical stream: a case study of Inyishi River, Southeastern Nigeria. Environ Monit Assess 2019;191(753):1-15.

11. Adeniyi AA, Afolabi JA. Determination of total petroleum hydrocarbons and heavy metals in soils within the vicinity of facilities handling refined petroleum products in Lagos Metropolis. Environ Int 2002; 28(1-2):79-82.

12. Li H, Yu L, Sheng G, Fu J, Peng P. Severe PCDD/F and PBDD/F pollution in the air around an electronic waste dismantling area in China. Environ Sci Technol 2007;41(16):5641-5646.

13. Akonye LA, Onwudiwe IO. Effects of certain soil amendment agents on lead $(\mathrm{Pb})$ uptake by plants grown on oil-polluted soil. Scientia Africana 2007;6(1):85-93.

14. Smith AH, Lingas EO, Rahman M. Contamination of drinking water by arsenic in Bangladesh: a public health emergency. Bull WHO 2000; 78(9):1093-1103.

15. Martin S, Griswold W. Human health effects of heavy metals. Environmental science and technology brief for citizens center for hazardous substance research. 2009;15:1-6. [cited 2018 Mar 20]. Available from: http://www.engg.ksu.edu/CHSR/files/chsr/outreach.

16. Abarikwu S, Iserhienrhien B, Badejo T Rutin-and selenium attenuated cadmium-induced testicular pathophysiology in rats. Hum Exp Toxicol 2013;32(4):395-406.

17. Occupational Safety and Health Administration (OSHA). Safety and health topics: Heavy metals. 2004. [cited 2018 Nov 15]. Available from: http://www.osha.gov/SLTC/metalsheavy/index.html.

18. Ibe FC, Opara AI, Ibe BO, Adindu BC, Ichu BC. Environmental and health implications of trace metal concentrations in street dust around some electronic repair workshops in Owerri, Southeastern Nigeria. Monit Assess 2018; 190(696):1-2.

19. Farombi AG, Adebayo OR, Oyekanmi AM. Impact of petroleum product on the soil around automobile workshops in Osun state, IOSR J Appl Chem (IOSR-JAC) 2013;4(1):13-15.

20. Obini U, Okafor CO, Afiukwa JN. Determination of levels of polycyclic aromatic hydrocarbons in soil contaminated with spent motor Engine oil in Abakaliki Auto-Mechanic Village. J Appl Sci Environ Manag 2013;17(2):169-175.

21. Arinze IE, Igwe O, Una C. Analysis of the heavy metals contamination in soil and water at automobile junk markets in Obosi and Nnewi, Anambra, South Eastern Nigeria. Arabian J Geosci 2015;8(12):1096110976.

22. Opara AI, Ibe FC, Njoku PC, Alinnor JI, Enenebaku CK. Geospatial and geostatistical analyses of particulate matter (PM10) concentrations in Imo State, Nigeria. International letters of Natural Sciences 2016;57:89-107.

23. Ibe FC, Isiuku BO, Enyoh CE. Trace metals analysis of soil and edible plant leaves from the abandoned municipal waste dumpsite in Owerri, Imo State, Nigeria. World News Nat Sci 2017;13:27-42.

24. Ibe FC, Opara AI, Duru CE, Isiuku BO, Enedoh MC. Statistical analysis of atmospheric pollutant concentrations in parts of Imo State, Southeastern Nigeria. Scientific African 2020;7:1-27.

25. Wong CSC, Duzgoren-Aydin NS, Aydin A, Wong MH. Evidence of excessive releases of metals from primitive e-waste processing in Guiyu, China. Environ Pollut 2007;148(1):62-72.

26. Yu XZ, Gao Y, Wu SC, Zhang HB, Cheung KC, Wong MH. Distribution of polycyclic aromatic hydrocarbons in soils at the Guiyu area of China, affected by the recycling of electronic waste using primitive technologies. Chemosphere 2006;65(9):1500-1509.

27. Ologunorisa RA, Ogobonaye JW. The Seasonal Incidence of Rainfall. Weather 1999;25:414-415. 
28. Iwuchukwu EI, Asoegwu SN, Okereke NAA. Modeling monthly relative humidity of Imo and Enugu states for evapotranspiration estimation. Int J Current Trends Eng Res 2018;4(10):1-8.

29. Akinsanola AA, Ogunjobi KO. Analysis of rainfall and temperature variability over Nigeria. Glob J Human Soc Sci: Geograph Environ Geosci 2014;14(3):1-18.

30. Chineke TC, Idinoba ME, Ajayi OC. Seasonal evapotranspiration signatures under a changing landscape and ecosystem management in Nigeria: Implications for agriculture and food security. Am J Sci Ind Res 2011;2(2):191-204.

31. Onyeagocha AC. Petrography and depositional environment of the Benin Formation Nigeria. J Mineral Geol 1980; 17:147-158.

32. British Geological Survey (2003). Quantitative groundwater maps for Africa, 32nd Review, 24-25.

33. Ibe KM. Migration of contaminants into groundwater at a landfill site. a case study of Avu landfill site, Owerri, SE Nigeria. Int J Environ Health Res 1999;9(1):55-66.

34. Ibe KM, Njemanze GN. The impact of urbanization and protection of water resources, Owerri, Nigeria. J Environ Hydrol 1998;6(9):1-9.

35. Esakku S, Palanivelu K, Kurian J. Assessment of heavy metals in a municipal solid waste dumpsite, Workshop on sustainable landfill management, Chennai, India, 3 - 5th December, 2003:139-145.

36. Dumitran C, Ion O, Florinel D. Spectroscopy and gas chromatographic measurements of TPH in soil samples contaminated with crude oil. Revista de Chimie, 2009;60(12):1335-1337.

37. Paíga P, Mendes L, Albergaria JT, Delerue-Matos CM. Determination of total petroleum hydrocarbons in soil from different locations using infrared spectrophotometry and gas chromatography Chemical Papers 2012;66(8):711-721.

38. Ogoko EC. Evaluation of polycyclic aromatic hydrocarbons, total petroleum hydrocarbons, and some heavy metals in soils of NNPC oil depot Aba Metropolis, Abia state, Nigeria. IOSR J Environ Sci Toxicol Food Technol 2014; 8(5):21-27.

39. United States Environmental Protection Agency (USEPA) (1996). Total recoverable petroleum hydrocarbon by infrared spectrophotometry (Method 8440). [cited 2019 Oct 12]. Available from:Washington, DC, USA: U.S. Government Printing Office. 8440-total-recoverable-petroleum-hydrocarbons-infrared-spectrophotometry

40. Cortes JE, Suspes A, Roa S, Gonzalez C, Castro HE. Total petroleum hydrocarbon by Gas Chromatography in Colombia waters and soil. American J Environ Sci. 2012;8(4):396-402.

41. Alinnor IJ, Nwachukwu MA. Determination of total petroleum hydrocarbon in soil and groundwater samples in some communities in Rivers State, Nigeria. J Environ Chem Ecotoxicol 2013;5(11):292-297.

42. Nor AF, Suhaimi A. Hazards due to polycyclic aromatic hydrocarbons (PAHs) and heavy metals at the closed Kubang Badak landfill, Selangor. Int J Environ Monitor Anal. 2013;1(2):71-77.

43. Daling PS, Faksness LG, Hansen AB, Stout SA. Improved and standardized methodology for oil spill fingerprinting. Environ Forensics 2002;3(3-4):263-278.

44. Rauckyte T, Zak S, Pawlak Z, Oloyede A. Determination of oil and grease, total petroleum hydrocarbons and volatile aromatic compounds in soil and sediment samples. J Environ Eng Landsc Manag, 2010;18(3):163-169.

45. Iturbe R, Flores C, Chavez C, Gonzalez A, Torres LG. In situ flushing of contaminated soils from a refinery: organic compounds and metal removals. Remed J 2004;14:141-152.

46. Yisa J, Jacob JO, Onoyima CC. Assessment of toxic levels of some heavy metals in road deposited sediments in Suleja, Nigeria. American J Chem 2012;2(2):34-37.

47. Edori O, Kpee S. Index models assessment of heavy metal pollution in soils within selected abattoirs in Port Harcourt, Rivers State. Singapore J Sci Res 2017;7:9-15.

48. Hakanson LL. An ecological risk index aquatic pollution control, a sedimentological approach. Water Res 1980;14(8):975-1001.

49. Department of Petroleum Resources (DPR). Department of petroleum resources environmental guidelines and standards for petroleum industry in Nigeria; 2002. [cited 2019 Sep 12]. Available from: https://dpr.gov.ng/index/egaspin/.

50. New South Wales State (NSW). New South Wales State environmental planning policies amendment (state and regionally significant development and law revision) New South Wales. 2018, 140.

51. Australian and New Zealand Environment and Conservation Council (ANZECC). Australian and New Zealand guidelines for fresh and marine water quality. National Water Quality anag Strategy 2000;1, 1-7, 314. [cited 2019 Oct 12]. Available from: https://www.waterquality. gov.au/sites/default/files/documents/anzecc-armcanz-2000-guidelines-voll.pdf

52. Ministry of Housing Spatial Planning and Environment (MHSPEN). Circular on target values and intervention values for soil remediation, Ministry of Housing Spatial Planning and Environment, Netherlands. [cited 2019 Oct 12]. Available from: http://esdat.net/Environmental\%20 Standards/Dutch/ENGELSE\%20versie\%20circulaire\%20Bodemsanering\%202009.pdf.

53. Danish Environmental Protection Agencym (DEPA). Guideline on remediation of contaminated sites, 2002 [cited 2019 Oct 12]. Available from: https://www2.mst.dk/udgiv/publications/2002/87-7972-280-6/ pdf/87-7972-281-4.pdf.

54. Nkansah MA, Christy AA, Barth T. The use of anthracene as a model compound in a comparative study of hydrous pyrolysis methods for industrial waste remediation. Chemosphere 2011;84(4):403-408.

55. Nouri N, Poorhashemi SA, Monavari SM, Dabiri F, Hassani AH. Legal criteria and executive standards of solid waste disposal subjected to solid waste management act. Int J Environ Res 2011;5(4):971-980.

56. World Health Organization (WHO). Drinking-water quality standard, world health organization guidelines (who) for drinking-water quality fourth edition 2011; [cited 2019 Oct 20]. Available from : https://www. epd.gov.hk/eia/register/report/eiareport/eia_2242014/EIA/app/ app02.02.pdf.

57. Jiao H, Wang Q, Zhao N, Jin B, Zhuang X, Bai Z. Distributions and sources of polycyclic aromatic hydrocarbons (PAHs) in soils around a chemical plant in Shanxi, China. Int. J Environ Res Public Health 2017;14(1198):1-19.

58. Katsoyiannis A, Sweetman AJ, Jones KC. PAH molecular diagnostic ratios applied to atmospheric sources: A critical evaluation using two decades of source inventory and air concentration data from the UK. Environ Sci Technol 2011;45(20):8897-8906.

59. Maliszewska-Kordybach B, Smreczak B, Klimkowicz-Pawlas A, Terelak $\mathrm{H}$. Monitoring of the total content of polycyclic aromatic hydrocarbons (PAHs) in arable soils in Poland. Chemosphere 2008; 
73(8):1284-1291.

60. Adedosu TA, Adeniyi OK, Adedosu HO. Distribution, sources and toxicity potentials of polycyclic aromatic hydrocarbons in the soil around the vicinity of Balogun-Birro dumpsite of Oshogbo, Nigeria. Malaysian J Anal Sci 2015;19(3):636-648. 